NOTE

\title{
A multiple-choice feeding-preference experiment utilising seagrasses with a natural population of herbivorous fishes
}

\author{
Simone Mariani* ${ }^{*}$ Teresa Alcoverro \\ Centre d'Estudis Avançats de Blanes (CSIC), Carretera Sta. Bàrbara s/n, 17300 Blanes, Spain
}

\begin{abstract}
We examined fish food preferences among the 9 most frequent seagrass species from Kenyan lagoonal areas. We tested the hypothesis that grazing fish prefer 'pioneering' seagrass species rather than 'climax' species. The experiment was conducted in situ in the Watamu Marine National Park (Kenya), with a natural population of herbivorous fish. The only fish observed eating seagrass leaves was Calotomus carolinus (family Scaridae), the second most abundant fish of the family in the park. The 3 variables tested (biomass eaten, \% of leaf eaten and leaf marks) revealed that there was a clear preference for 'pioneering', short-lived species such as Cymodocea rotundata and Syringodium isoetifolium over 'climax', long-lived species such as Enhalus acoroides and Thalassodendron ciliatum (Friedman's test, $p<0.005$ ). The good correlation found between total carbon content and leaf marks indicated that fishes also prefer low 'carbon-fiber' plant species instead of high carbon content species. This study ascertains the feeding behaviour of fish species and suggests new ways of understanding the complicated relationships that bind herbivores and seagrasses, highlighting the role of grazing fish in influencing seagrass abundance and distribution.
\end{abstract}

KEY WORDS: Food preference - Herbivorous fish - Seagrasses - Halodule wrighti - Halodule uninervis Halophila stipulacea . Syringodium isoetifolium . Cymodocea rotundata. Enhalus acoroides - Thalassia hemprichij - Thalassodendron ciliatum $\cdot$ Cymodocea serrulata $\cdot$ Calotomus carolinus

Seagrass beds are one of the most abundant marine ecosystems in Indian Ocean coastal areas, where they sustain high primary production and provide habitat and food for several fish taxa (Fortes 1995, Vermaat et al. 1995, Wakibya 1995, Agawin et al. 1996). Seagrasses can support high herbivore abundance compared with other aquatic macrophytes (Ogden 1980, Ogden et al. 1980, Cyr \& Pace 1993, Cebrián 1996),

•E-mail: simone@ceab.csic.es with consumption in the tropics ranging from 5 to $90 \%$ of the leaf production (Klumpp et al. 1993, Valentine \& Heck 1991, Cebrián \& Duarte 1998).

Fish herbivory, representing the trophic interactions that take place at the base of the marine food web (Horn 1989), plays an important role in structuring near-shore marine ecosystems. Herbivores have been shown to contribute significantly in determining algal cover in coral reef ecosystems (Hay 1981, Hay et al. 1983, Carpenter 1986, McClanahan 1997), and in influencing seagrass community structure (McClanahan 1994). However, little is known about the consequence of fish herbivory on the relative abundance and composition of tropical seagrasses.

In recent years a large effort has been made to evaluate the relationships that bind fishes and marine plants (algae and seagrasses). The most frequently utilised approaches to the study of herbivory in seagrasses are gut content analysis (Sala 1996. Havelange et al. 1997), clipping assays (Cebrián et al. 1998) and leaf bite observations (Alcoverro et al. 1997 , Cebrián \& Duarte 1998). A vast majority of these studies have been conducted in rel-atively simple, monospecific seagrass habitats. No efforts have been made to evaluate the fish feeding preferences in more complex multispecific seagrass areas.

The Kenyan coast seagrass flora is characterised by 12 species of seagrasses (Wakibya 1995). Nearly all of these species represent 2 contrasting life-history strategies: short-lived, 'pioneering' forms comprising Halophila ovalis, Halophila minor, Cymodocea rotundata, Halodule uninervis, Halodule wrightii, Halophila stipulacea, Syringodium isoetifolium, Zostera capensis, and long-lived, 'climax' species represented by Enhalus acoroides, Thalassia hemprichii, Thalassodendron ciliatum (Gallegos et al. 1994, Vermat et al. 
1995, Duarte et al. 1996). The species Cymodocea serrulata is peculiar due to differences in its rhizome growth rates (cf. Vermaat et al. 1995, Brouns 1987).

Enhalus acoroides and Thalassia hemprichii are defined as 'constant' species (Vermaat et al. 1995), in relation to their capacity for occupying space more permanently. These species are found either in mixed meadows or as monospecific stands. The most common species to occur as monospecific meadows are Thalassodendron ciliatum and T. hemprichii (Wakibya 1995). This characteristic situation (mixed seagrass meadows) provided, therefore, a unique opportunity to test seagrass preference of herbivorous fish in situ. Parrotfishes, apart from being a major component of the herbivorous fish community (Bruggemann et al. 1994), seem to be the most important fish group feeding on seagrasses in Kenya (McClanahan et al. 1994).

The aim of the current experiment was to ascertain herbivorous fish preferences for seagrasses inside a marine park and thereby elucidate possible implications for seagrass species distribution.

Materials and methods. The study was conducted in the Watamu Marine National Park lagoon off the coast of Kenya $\left(03^{\circ} 22^{\prime} \mathrm{S}, 39^{\circ} 59^{\prime} \mathrm{E}\right)$. The park is characterised by the presence of 12 seagrass species and it has a high biomass of fish. Values of total wet weight of fish are about 10 times higher than in areas outside the park (McClanahan 1997). The experiment was performed in a subtidal seagrass-free area inside the lagoon, between a monospecific Thalassodendron ciliatum meadow and the coral and hard-substrate-dominated lagoonal area (McClanahan et al. 1994).

The 9 most frequent seagrass species growing in the park (Halodule wrightii, Halodule uninervis, Halophila stipulacea, Syringodium isoetifolium, Cymodocea serrulata, Enhalus acoroides, Thalassia hemprichii, Thalassodendron ciliatum, Cymodocea rotundata) were chosen for the experiment. Shoots of

Table 1 Initial number of shoots and leaves and leaf lengths in the experimental plots for each species. Due to the particular features of $H$. stipulacea, pieces of horizontal rhizome taken. Numbers of leaves for each rhizome are shown

\begin{tabular}{|lccc|}
\hline \multicolumn{1}{|c}{ Plant } & $\begin{array}{c}\text { Leaf length } \\
(\mathrm{cm})\end{array}$ & $\begin{array}{c}\text { No. of leaves } \\
\text { per shoot }\end{array}$ & $\begin{array}{c}\text { No. of shoots } \\
\text { per sample }\end{array}$ \\
\hline Enhalus acoroides & 30 & 3 & 3 \\
Thalassodendron ciliatum & 8 & 5 & 3 \\
Cymodocea serrulata & 12 & 3 & 4 \\
Syringodium isoetifolium & 15 & 1 & 10 \\
Halodule uninervis & 12 & 2 & 7 \\
Halophila stipulacea & - & $17,23,25,17,19$ & - \\
Thalassia hemprichii & 10 & 2 & 5 \\
Cymodocea rotundata & 15 & 2 & 6 \\
Halodule wrightii & 10 & 1 & 15 \\
\hline
\end{tabular}

each plant species were prepared for the experimental assays considering differences in size and form (Table 1).

We harvested shoots of the 9 seagrass species and transported them to the laboratory in a cool box maintained at $20^{\circ} \mathrm{C}$ on the day before the field experiment. In the laboratory we selected shoots with leaves without bite marks or, when all the shoots had marks, we cut the tips of the leaves. We tied between 3 and 15 selected shoots of each species together; each group consisted of approximately 15 leaves. The number of shoots in each 'group' differed due to the large differences in the number of leaves per shoot among the species. For instance, while Halodule uninervis samples were prepared using 15 shoots, each with a single leaf, Thalassodendron ciliatum was prepared using 3 shoots (and the rhizome), each with 5 leaves. We prepared a total of 45 groups of tied leaves and thus 5 replicate groups per species. The initial leaf length of each group was recorded (Table 1). We attempted to retain the original appearance of the species, as normally encountered in the field, disregarding the final obvious differences in size among the plants themselves. This served to balance the number of leaves of each species used in the assay, and reproduced how these species naturally appear in seagrass meadows.

The following day, in the field, 9 groups of shoots (i.e. 1 of each species) were arranged in a circle of $3 \mathrm{~m}$ in diameter. Five such circles were set up between the seagrass meadow and the coral patches, assuring that the distance of each replicate circle from the meadow and the corals was the same. A $20 \mathrm{~m}$ distance was maintained between each circle of experimental plants.

Two divers recorded fish species feeding and behaviour in the circles during a $2 \mathrm{~h}$ period after the experiment was set up. All shoots were removed $24 \mathrm{~h}$ after the start of the experiment; no plant deterioration was recorded at this time. The presence or absence of bite marks per leaf and final leaf-length measurements were recorded for all the samples.

Additional shoots ( 3 per species) representing 'climax' species (Thalassia hemprichii, Cymodocea serrulata and Thalassodendron ciliatum) and 'pioneering' species (Cymodocea rotundata, Syringodium isoetifolium and Halodule uninervis) were collected at random and dried at $70^{\circ} \mathrm{C}$ until constant weight. Total carbon and nitrogen on seagrass leaves were determined using a CarloErba CHN Analyser.

We analysed all data with a non-parametric Friedman's test as is recommended in Roa 
(1992) for the cases in which parametric statistics cannot be applied and the number of variables is $\geq 5$.

Results and discussion. Calotomus carolinus (family Scaridae) was the only fish observed eating plant leaves from the plots in our $2 \mathrm{~h}$ observation (a total of 20 observations in the 5 plots). In the field, this species was regularly identified as mainly responsible for the fish bite marks observed on plant leaves. C. carolinus is the second most abundant fish of the family in the park (McClanahan 1997), and is recognised as an algae and seagrass grazing parrotfish (Smith 1986, Lieske \& Myers 1997). Leptoscarus vaigensis, another well-known seagrass eating parrotfish, was not seen around the plots while they were being prepared or in subsequent direct observations.

Most of the plant samples collected after $24 \mathrm{~h}$ from the field showed signs of herbivory. The bite marks observed were ring-shaped and very cleanly cut compared with the clearly jagged marks of sea urchin herbivory (see Fig. 2 in McClanahan et al. 1994). Herbivorous sea urchins are almost absent in this area (McClanahan et al. 1994, unpubl. data). For these reasons we assume that all the analysed shoots were bitten by Calotomus carolinus or other seagrass-eating parrotfish.

Our experiment offered several seagrass species simultaneously to herbivorous fish, to avoid the difficulties inherent in separate-offer designs. Separateoffer designs have been criticised for not addressing the subject of food feeding preference, since no food choice is offered to the consumer (Peterson \& Renauld 1989). Furthermore, it has been demonstrated by several authors that when offered no choice consumers may utilise less preferred food at higher rates to compensate for the low nutritional value of the offered species (Roa 1992).

We used the leaf bite marks (presence or absence), $\mathrm{cm}$ of leaf eaten and percentage of leaf consumed (relative to the initial) to test fish preferences among seagrass species. There was a significant difference in the presence of bite marks per leaf among the 9 plant species $(\mathrm{p}<0.0043, \mathrm{n}=5$, Friedman's test). Enhalus acoroides, Thalassodendron ciliatum and Cymodocea serrulata were poorly bitten seagrass species, while the other species showed bite frequency higher than $50 \%$ (Fig. 1). None of the plants offered were ignored by fishes (Fig. 1). This comparison can only inform us about plant choice, but gives us no clue about the biomass eaten. This can, however, be estimated by analysing the $\mathrm{cm}$ of leaf eaten. We also found highly significant differences in $\mathrm{cm}$ of leaf eaten $(\mathrm{p}<0.0008$, $\mathrm{n}=5$, Friedman's test, Fig. 1). It is important to highlight that the tallest, long-lived plants, such as $E$. acoroides and $T$. ciliatum, were almost untouched, while small, short-lived plants, such as $C$. rotundata and Syringodium isoetifolium, were completely eaten,

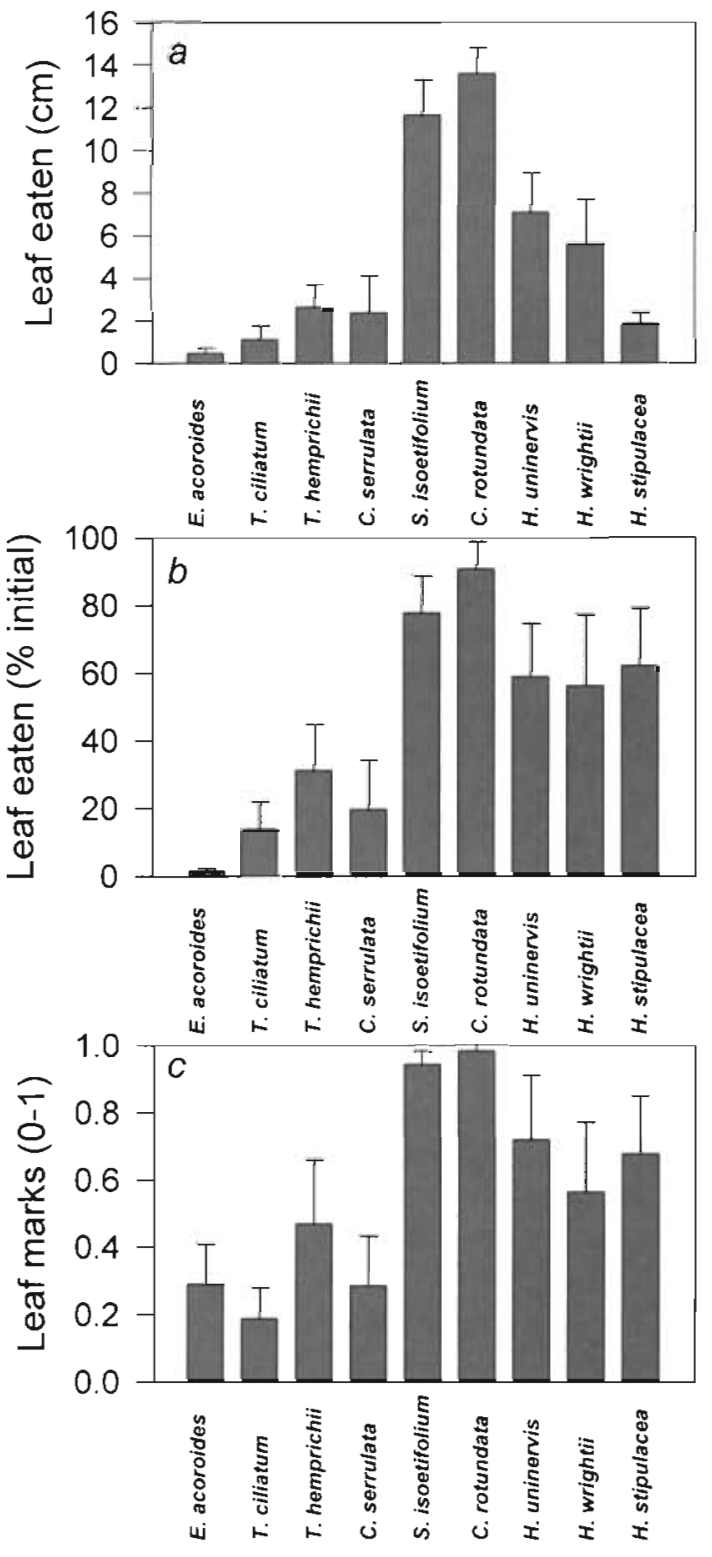

Fig. 1. (a) Amount of leaf eaten (cm), (b) percentage of initial leaf length eaten, and (c) average of the leaf marks, for the 9 seagrass species utilised. Mean and standard errors are shown

indicating that fishes do not choose the biggest and most evident plants. The case of Halophila stipulacea, for which we found few cm eaten, is unusual because leaves do not exceed lengths of $4 \mathrm{~cm}$ (Fig. 1).

In order to avoid the problem of leaf length discrepancy between different species, we calculated the percentage of leaf eaten. Once again, we found significant differences ( $p<0.0027, n=5$, Friedman's test). Using this approach, small-leaf plants such as Halophila stipulacea and Halodule uninervis emerge as the most preferred species together with Cymodocea rotundata and Syringodium isoetifolium, while Enhalus acoroides 
Table 2. Percentage of nitrogen and carbon $(\% \mathrm{~N}, \% \mathrm{C})$ and carbon-nitrogen ratio $(\mathrm{C}: \mathrm{N})$ in the leaves of 6 selected plants representing 'pioneering' and 'climax' forms. Data represent average values (and SD) of 3 samples

\begin{tabular}{|cccccc|}
\hline \multicolumn{1}{c}{ Plant } & $\% \mathrm{~N}$ & \multicolumn{2}{c}{$\% \mathrm{C}$} & $\mathrm{C}: \mathrm{N}$ \\
\hline $\begin{array}{c}\text { Cymodocea } \\
\text { rotundata }\end{array}$ & 3.1 & $(0.08)$ & 39.5 & $(0.15)$ & 128 \\
$\begin{array}{c}\text { Thalassia } \\
\text { hemprichii }\end{array}$ & 2.8 & $(0.06)$ & 39.1 & $(0.3)$ & 14.1 \\
$\begin{array}{c}\text { Cymodocea } \\
\text { serrulata }\end{array}$ & 3 & $(0.09)$ & 41 & $(0.51)$ & 15.7 \\
$\begin{array}{c}\text { Thalassodendron } \\
\text { ciliatum }\end{array}$ & 3 & $(0.06)$ & 42.1 & $(0.03)$ & 16.4 \\
$\begin{array}{c}\text { Syringodium } \\
\text { isoetifolium }\end{array}$ & 2.1 & $(0.08)$ & 36.6 & $(0.28)$ & 17.5 \\
$\begin{array}{c}\text { Halodule } \\
\text { uninervis }\end{array}$ & 2 & $(0.17)$ & 39 & $(0.71)$ & 19.3 \\
\hline
\end{tabular}

and Thalassodendron ciliatum were the least preferred of the species offered (Fig. 1).

We found no correlation between leaf marks, percentage of leaf eaten or $\mathrm{cm}$ of leaf eaten and nitrogen content (Table $2, p>0.05$ ). The carbon:nitrogen or total nitrogen ratio, a widely used index of nutritional quality, has been described as not always being appropriate when comparing seagrasses. Part of this nitrogen may be inorganic or associated with non-protein amino acids and protein complexes of no known nutritional value (Klumpp et al. 1989). In contrast, good correlation was found when we compare leaf marks and total carbon content (Fig. 2). These results can be explained by a preference for low 'carbon-fiber' plant species instead of high carbon content species. These organoleptic properties could explain fish preference

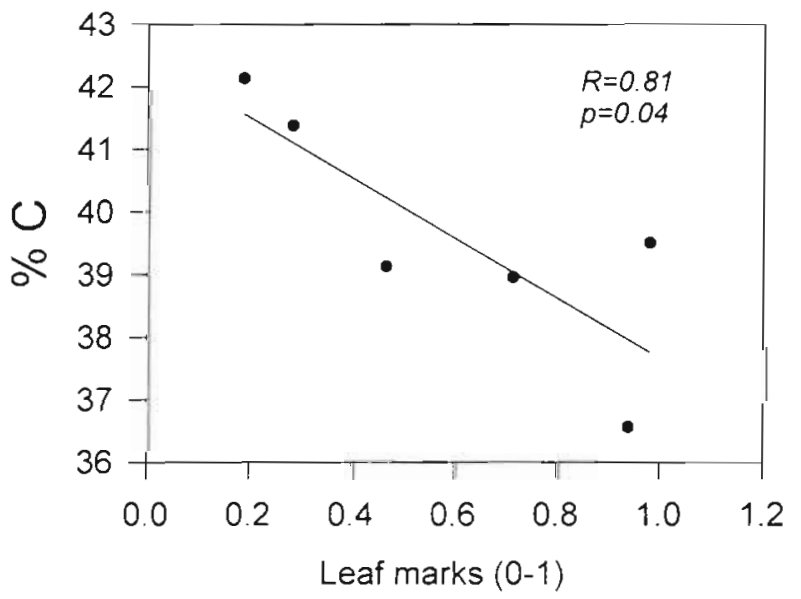

Fig. 2. Average of the leaf marks $(n \geq 45)$ in relation to the average of total carbon content $(n=3)$ for the 6 species analysed for 'pioneering' seagrasses such as Syringodium isoetifolium and Cymodocea rotundata. In contrast, sea urchins have been described to control the abundance of some long-lived, 'climax' plants such as Thalassia testudinum (Tertschnig 1989, Valentine \& Heck 1991) and T. hemprichii (Klumpp et al. 1993).

Our results indicate that grazing fishes like Calotomus carolinus may not have the same impact on the biomass and on the abundance of 'climax' seagrasses like Thalassodendron ciliatum and Thalassia hemprichii as observed for sea urchins. However, they could play a key role in controlling the proliferation of new 'pioneering' species. We are tempted to interpret these results as representing an ecological equilibrium in which herbivorous fish control short-lived seagrass species, eliminating them from the community, thus allowing long-lived species to establish and proliferate. Multispecific seagrass communities are dependent on several factors (light irradiance, nutrient concentration, tide-dependent air exposure, etc.) and it is difficult and naive to implicate a single structuring force as responsible for the observed seagrass community. However, as we illustrate in this paper, herbivorous fish can play a significant role in structuring seagrass communities, influencing both the plant biomass and species composition.

Acknowledgements. We are indebted to Dr Tim McClanahan and the Kenyan Wildlife Service's Watamu Marine National Park guards for field assistance. Financial support for this work was provided by a Post Doctoral Training Grant (Ministerio de Educación y Ciencia) to T.A. Special thanks go to our friends Dr Nuria Marbà and Rohan Arthur for their unique review of the paper.

\section{LITERATURE CITED}

Agawin NSR, Duarte CM, Fortes MD (1996) Nutrient limitation of Philippine seagrasses (Cape Boliano, NW Philippines): in situ experimental evidence. Mar Ecol Prog Ser 138:233-243

Alcoverro T, Duarte CM, Romero J (1997) The influence of herbivores on Posidonia oceanica epiphytes. Aquat Bot $56: 93-104$

Brouns JJWM (1987) Growth patterns of some Indo-WestPacific seagrasses. Aquat Bot 28:39-61

Bruggemann JH, Begeman J, Bosma EM, Verburg P, Breeman AM (1994) Foraging by the stoplight parrotfish Sparisoma viride. II. Intake and assimilation of food, protein and energy. Mar Ecol Prog Ser 106:57-71

Carpenter RC (1986) Partitioning herbivory and its effects on coral reef algal communities. Ecol Monogr 56:345-363

Cebrián J (1996) The fate of autotrophic production with special reference to herbivory: from seagrasses to some general patterns among plant communities. PhD thesis, UPC Universitat Politécnica de Catalunya, Barcelona

Cebrián J, Duarte CM (1998) Patterns in leaf herbivory on seagrasses. Aquat Bot 60:67-82

Cebrián J, Duarte CM, Agawin N, Merino M (1998) Leaf 
growth response to simulated herbivory: a comparison among seagrass species. J Exp Mar Biol Ecol 220:67-81

Cyr H, Pace M (1993) Magnitude and patterns of herbivory in aquatic and terrestrial ecosystems. Nature 361:148-150

Duarte CM, Hemminga MA, Marbà N (1996) Growth and population dynamics of Thalassodendron ciliatum in a Kenyan back-reef lagoon. Aquat Bot 55:1-11

Fortes MD (1995) Seagrasses of East Asia: environmental and management perspectives. RCU/EAS Technical Report Series, United Nations Environment Programme 6, Bangkok

Gallegos ME, Merino M, Rodriguez A, Marbà N, Duarte CM (1994) Growth patterns and demography of pioneer seagrasses Halodule wrightii and Syringodium filiforme. Mar Ecol Prog Ser 109:99-104

Havelange S, Lepoint G, Dauby P, Bouquegneau JM (1997) Feeding of the sparid fish Sarpa salpa in a seagrass ecosystem: diet and carbon flux. PSZN I: Mar Ecol 18: 289-297

Hay ME (1981) Spatial patterns of grazing intensity on a Caribbean barrier reef: herbivory and algal distributions. Aquat Bot 11:97-109

Hay ME, Colburn T, Dowing D (1983) Spatial and temporal patterns in herbivory on a Caribbean fringing reef: the effects on plant distribution. Oecologia 58:299-308

Horn MH (1989) Biology of marine herbivorous fishes. Oceanogr Mar Biol Annu Rev 27:167-272

Klumpp DW, Howard RT, Pollard D (1989) Trophodynamics and nutritional ecology of seagrass communities. In: Larkum AWD, McComb AJ, Shepherd SA (eds) Biology of seagrasses: a treatise of the biology of seagrasses with special reference to the Australian region. Elsevier, Amsterdam, p 394-457

Klumpp DW, Salita-Espinosa JT, Fortes MD (1993) Feeding ecology and trophic role of sea urchins in a tropical seagrass community. Aquat Bot 45:205-229

Editorial responsibility: Otto Kinne (Editor), Oldendorf/Luhe, Germany
Lieske E, Myers R (1997) Coral reef fishes. Princeton University Press, Princeton, NJ

McClanahan TR (1997) Primary succession of coral-reef algae: differing patterns on fished versus unfished reefs. J Exp Mar Biol Ecol 218:77-102

McClanahan TR, Nugues M, Mwachireya S (1994) Fish and sea urchin herbivory and competition in Kenyan coral reef lagoons: role of reef management. J Exp Mar Biol Ecol $184: 237-254$

Ogden JC (1980) Faunal relationships in Caribbean seagrass beds. Garland STPM, New York

Ogden JC, Tighe S, Miller S (1980) Grazing of seagrasses by large herbivores in the Caribbean. Am Zool 120: 949-950

Peterson CH, Renauld PE (1989) Analysis of feeding preference experiments. Oecologia 80:82-86

Roa R (1992) Design and analysis of multiple-choice feedingpreference experiments. Oecologia 89:509-515

Sala E (1996) The role of fishes in the organization of a Mediterranean sublittoral community. PhD thesis, University of Marseille

Smith M (1986) Smith's sea fish. Springer Verlag, Berlin

Tertschnig WP (1989) Diel activity patterns and foraging dynamics of the sea urchin Tripneustes ventricosus in a tropical seagrass community and a reef environment (Virgin Isalnds). Mar Biol 10:3-21

Valentine J, Heck K Jr (1991) The role of sea urchin grazing in regulating subtropical seagrass meadows: evidence from field manipulations in the northern Gulf of Mexico. J Exp Mar Ecol Biol 154:215-230

Vermaat JN, Agawin N, Duarte CM, Fortes MD, Marbà N (1995) Meadow maintenance, growth and productivity of a mixed Philippine seagrass bed. Mar Ecol Prog Ser 124: 215-225

Wakibya JG (1995) The potential human-induced impacts on the Kenya seagrasses. UNESCO Rep Mar Sci 66:176-187

Submitted: March 31, 1999; Accepted: July 13, 1999

Proofs received from author(s): November 15, 1999 